\title{
NOTES
}

\section{CHARACTERIZATION OF THE CYTOTOXIC ACTIVITY OF VERMICULINE}

\author{
K. Horáková, B. Kernáčová, P. Nemec \\ and J. FUskA
}

Department of Microbiology and Biochemistry, Slovak Technical University, 88037 Bratislava, Jànska 1, Czechslovakia

(Received for publication July 1, 1976)

Vermiculine is a new cytotoxic antibiotic of the macrolide group isolated from the fermentation broth of Penicillium vermiculatum DANGEARD. ${ }^{1)}$ It is active against Gram-positive bacteria, Trypanosoma cruzi and Leishmannia braziliensis. However, only very weak activity against yeasts or Mycobacteria was noted. Another property of this new antibiotic is its antitumor activity. ${ }^{2}$ The present paper deals with the characterization of the lethal effect of vermiculine.

The proliferation of HeLa and L 5178Y cells during the permanent exposure to various con-

Fig. 1. Proliferation of HeLa and L 5178Y cells during exposure to various concentrations of vermiculine (in $\mu \mathrm{g} / \mathrm{ml}$ ).

Exponentially growing HeLa cells in MÜLLER flasks and L 5178Y cells in stationary tubes $(15 \times$ $100 \mathrm{~mm}$ ) both containing $5 \mathrm{ml}$ culture set up with $5 \times 10^{4}$ cells $/ \mathrm{ml}$ were treated for 72 hours with vermiculine dissolved in dimethylsulfoxide (DMSO). Control cultures received an identical concentration $(1 \%$ ) of DMSO.

Conditions of cultivation were similar as previously described ${ }^{3) 4}$.

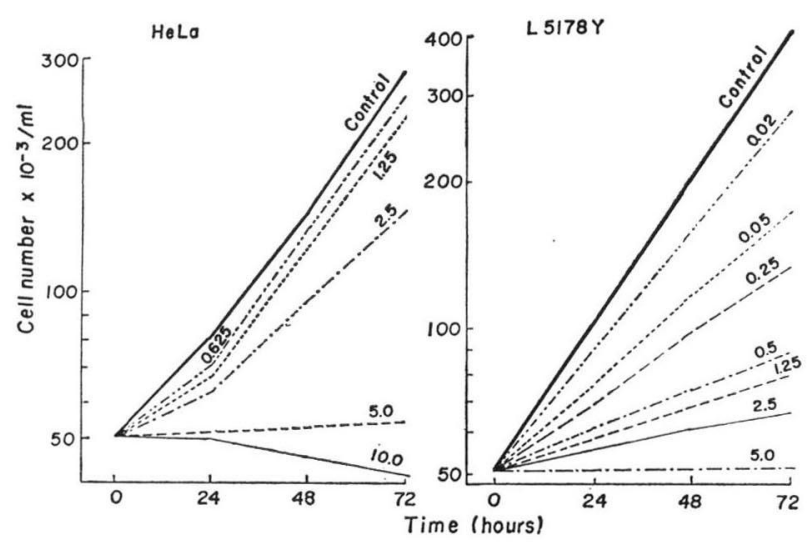

Table 1.

\begin{tabular}{c|c|c|c}
\hline \multirow{2}{*}{$\begin{array}{c}\text { Incubation } \\
\text { time in } \\
\text { hours }\end{array}$} & Control & \multicolumn{3}{|c}{ Mermiculine $(\mu \mathrm{g} / \mathrm{ml})$} \\
\cline { 2 - 4 } & & 1.25 & 2.5 \\
\hline 24 & 49 & 55 & 63 \\
48 & 48 & 60 & 66 \\
72 & 53 & 53 & 68 \\
\hline
\end{tabular}

centrations of vermiculine was followed (Fig. 1). At the tested doses retardation of cell replication was observed which was related to the antibiotic concentration. The data indicated that L 5178Y cells were more sensitive to vermiculine than HeLa cells. Similarly FusKa et al. ${ }^{2)}$ observed that mouse lymphoma was the most sensitive model during the study of the possible cancerostatic effect of vermiculine.

To characterize the cytotoxic effect of vermiculine further experiments on HeLa cells were performed. As seen in Table 1, the frequency with which mitosis occurred in the treated cultures increased within 24 hours at both tested doses of vermiculine. In addition to the increase of mitotic index, vermiculine interfered with the cellular content of nucleic acids and protein. Changes in the amounts of RNA, DNA and protein per $10^{B}$ cells resulting from exposure of the cells are illustrated in Fig. 2. During the first 24-hour treatment a statistically significant decrease occurred in the RNA content per cell. A more pronounced decrease in cellular DNA was also apparent at this time. On the other hand the protein content per cell increased to $160 \%$ and $190 \%$ of control value in a 24-hour interval after the drug addition. At the same time the glucose consumption was only slightly inhibited by vermiculine (Fig. 3) at the tested concentrations.

In parallel with the mentioned experiments the cell volumes were also determined. The treated cells increased in size, reaching maximum values at 24 hours, as may be seen in Table 2 where the changes in mean cell volumes are presented. When RNA, DNA and pro- 
Fig. 2. Cell content of DNA, RNA and protein during the cytotoxic reaction of vermiculine on HeLa cells. Portions of cells collected by centrifugation, washed once with $0.9 \% \mathrm{NaCl}$ and then resuspended in the latter were used for determinations of cell number, protein and nucleic acids content as described previously. ${ }^{3)}$
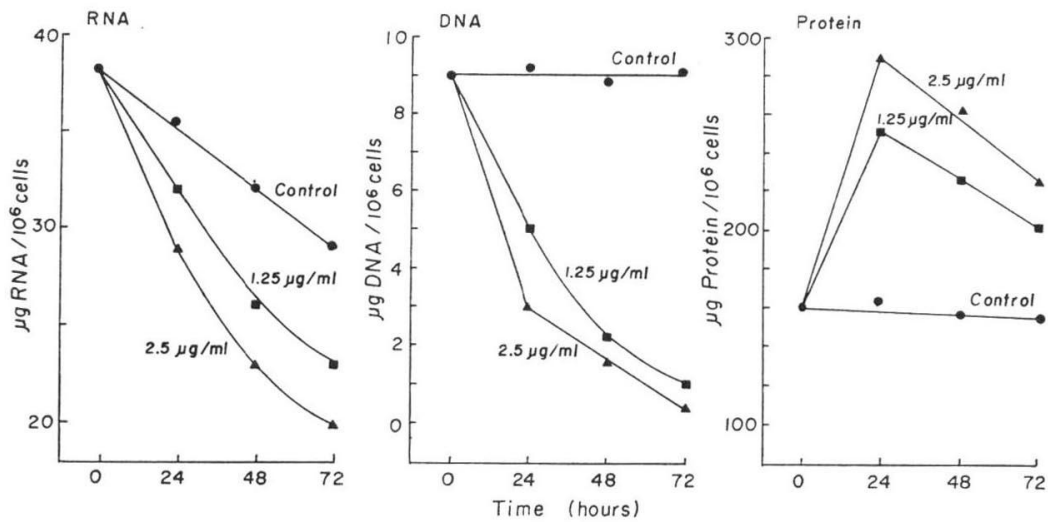

Fig. 3. Glucose consumption by HeLa cells in the presence and absence of vermiculine.

Glucose concentration in the culture medium was determined by using the Bio-La-test (Lachema, Brno).

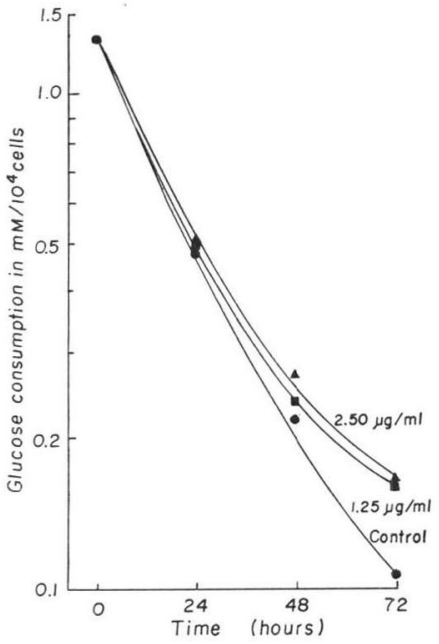

Table 2. Enlargement of HeLa cells produced by vermiculine.

\begin{tabular}{c|c|c|c}
\hline \multirow{2}{*}{$\begin{array}{l}\text { Hours after } \\
\text { addition of }\end{array}$} & \multicolumn{3}{|c}{ Mean cell volume in $\mu \mathrm{m}^{3} \times 10^{2}$} \\
\cline { 2 - 4 } vermiculine & 0.00 & 1.25 & 2.50 \\
\cline { 2 - 4 } & 19.8 & 30.5 & 33.9 \\
24 & 20.0 & 24.8 & 31.5 \\
48 & 21.0 & 26.6 & 29.4 \\
72 & &
\end{tabular}

tein content were expressed in terms of a unit cell volume (Table 3 ) it was found that in vermiculinetreated cells the relation between these parameters were disturbed. While increases in protein content occurred that was proportionately larger than increases in cell volume, the content of RNA and particularly of DNA per unit cell volume considerably decreased.

From the results presented, it is apparent that the cytotoxic effect of the antibiotic is characterized by unbalanced growth in which protein: cell number ratios increased and nucleic acids

Table 3. DNA, RNA and protein content per unit volumes in HeLa cells during the exposure to vermiculine (V)

\begin{tabular}{|c|c|c|c|c|c|c|c|c|c|}
\hline \multirow{3}{*}{$\begin{array}{l}\text { Hours } \\
\text { after } \\
\text { addition } \\
\text { of ver- } \\
\text { miculine }\end{array}$} & \multicolumn{3}{|c|}{$\underset{\mu \mathrm{g} / \mu \mathrm{m}^{3} \times 10^{9}}{\text { DNA }}$} & \multicolumn{3}{|c|}{$\underset{\mu \mathrm{g} / \mu \mathrm{m}^{3} \times 10^{9}}{\text { RNA }}$} & \multicolumn{3}{|c|}{$\begin{array}{l}\text { Protein } \\
\mu \mathrm{g} / \mu \mathrm{m}^{3} \times 10^{9}\end{array}$} \\
\hline & \multirow{2}{*}{$\begin{array}{l}\text { Cont- } \\
\text { rol }\end{array}$} & \multicolumn{2}{|c|}{$\mu \mathrm{g} \mathrm{V}$} & \multirow{2}{*}{$\begin{array}{l}\text { Cont- } \\
\text { rol }\end{array}$} & \multicolumn{2}{|c|}{$\mu \mathrm{g} \mathrm{V}$} & \multirow{2}{*}{$\begin{array}{c}\text { Cont- } \\
\text { rol }\end{array}$} & \multicolumn{2}{|c|}{$\mu \mathrm{g} \mathrm{V}$} \\
\hline & & 1.25 & 2.5 & & 1.25 & 2.5 & & 1.25 & 2.5 \\
\hline 24 & 3.7 & 1.8 & 0.9 & 13.8 & 11.1 & 9.5 & 63.5 & 91.2 & 96.3 \\
\hline 48 & 4.2 & 0.8 & 0.5 & 16.1 & 10.5 & 7.3 & 78.0 & 90.3 & 84.5 \\
\hline 72 & 4.1 & 0.4 & 0.2 & 13.7 & 9.0 & 6.8 & 67.8 & 74.2 & 78.4 \\
\hline
\end{tabular}


decreased. The vermiculine induced increase in cell size accompanied with accumulation of protein and decrease in DNA and RNA content, which occurred as cell proliferation decelerated, imply that cells synthesized protein (but no nucleic acids) without entering into mitosis. There are strong indications that the dying cells are in late $G_{1}$ phase or at the $G_{1} / S$ transition of the cell cycle. Furthermore, interference with the energy metabolism was not a prerequisite for vermiculine's lethal effect on HeLa cells.

\section{References}

1) Fuska, J.; P. Nemec \& I. Kuhr: Vermiculine, a new antiprotozoal antibiotic from Penicillium vermiculatum. J. Antibiotics 25: 208 213, 1972

2) FusKa, J.; L. IVANITSKaya, K. HORÁKOVÁ \& I. KuHR: The cytotoxic effects of a new antibiotic vermiculine. J. Antibiotics 27: 114 142,1974

3) Horáková, K.; J. Navarová \& A. R. P. PaterSON: The delayed cytotoxic effect of 6-mercaptopurine. Characterization of the unbalanced growth in HeLa cells produced by 6mercaptopurine. Biochim. Biophys. Acta 366: $333 \sim 340,1974$

4) Tidd, D. M.; S. C. KIM, K. HorÁkovÁ, A. Moriwaki \& A. R. P. PAterson: A delayed cytotoxic reaction for 6-mercaptopurine. Cancer Res. 32: 317 322, 1972 